\title{
New Dimensions of Management Theory
}

\begin{abstract}
The author identifies good organization and management as a vital factor in library operation. He attempts to acquaint the reader briefly with the history and development of management science from the Classical theorists and Scientific Management school through the Human Relations school up to the modern behavioralist and problemoriented approach. He shows the influence of these different approaches on library management up to the present and suggests ways in which library managers could make further use of the vast body of theory and research in the management field. He recommends more utilization of existing knowledge along with further research by librarians into management problems.
\end{abstract}

$\mathrm{T}$ HE LIBRARY, all will agree, is a form of organization. An organization may be defined as that which coordinates a large number of people to perform explicitly defined objectives which the individual cannot perform alone. It emphasizes rationality, effectiveness, and efficiency in the achievement of organizational objectives.

One of the most important factors in the successful fulfillment of library function is good management and organization. Wilson and Tauber, in The University Library, concluded that "the success of the library in performing its appropriate function depends, in considerable measure, upon the nature of its administrative organization."1

\footnotetext{
${ }^{1}$ L. R. Wilson and M. F. Tauber, The University Library (2d ed. New York; Columbia University Press, $1956)$, p. 125.
}

$\mathrm{Mr}$. Oh is project assistant at the University of Wisconsin Medical School Library. He wishes to express his gratitude to Virginia Holtz, Medical Librarian there, and to Professor Alan C. Filley, Associate Director of the Industrial Relations Research Institute at Wisconsin, for having read the manuscript of this paper and for having made useful suggestions upon it.
In order to fulfill library objectives, then, there is little doubt that librarians should be aware of the continuing development of an accurate theory of management and organization, and its proper application to the real world as reflected in current management practice. The role society now demands of the library has become so great that libraries will have to advance in many areas in order to keep up to these expectations. The following paragraphs outline the field of management and organization up to the present and offer some of the new guidelines and insights that have been developed for the consideration of students, library administrators, and teachers of library science.

Main stream of library management literature drawn from Classical Organization theories. Library literature shows that library management has drawn heavily from classical organization theories. These theories can be divided into two different schools of thought. The first is what students of library management and organization call Scientific Management and the second may be called Classical Organization theory. 
In 1912 Frederick Taylor and his associates promulgated the Scientific Management theory. The basic assumption of their philosophy was that workers are economically motivated. The worker will respond with his best efforts, they promised, if material rewards are closely related to work efforts. They focused their attention on the production unit, or shop, and they considered the workers from a physical standpoint, as adjuncts to their machines.

This emphasis on motivation by material reward popularized the prescriptive approach to efficient organization and the conduct of routine work. Examples of this approach are the famous time and motion studies, incentive pay plans, and specialization according to function. Managers were taught that improved organizational efficiency automatically increases profits and reduces waste, resulting in more material rewards to workers. They expected these principles to help them achieve the desired efficiency.

In the 1930's Fayol (in translation), Mooney and Reiley, Gulick and Urwick, R. C. Davis, Max Weber, and others originated Classical Organization theory. This school, unlike Scientific Management, embraced the whole organization rather than an isolated production unit or shop. It considered organization units or departments to be coordinated parts in a system.

In this theory, the main principle is the division of labor. From this all the other elements flow. It advised managers to break down complicated jobs into more specialized activities. This was supposed to result in more highly skilled workers who could carry out their jobs more efficiently. Under this principle of specialization, work was divided according to the task, process, type of clientele, geographic area, and the like.

Classical Organization theorists balanced division of labor by the principle of unity of command. Authority through unity of command resulted in "pyramids" of control. The chief executive exercises his authority through descending chains of command. The problem of span of control arises in this situation, as well as supervision, departmentalization, and levels of authority. It is hardly necessary to mention that this school also emphasizes the formal aspects of organization.

Present-day library management is discipline-oriented. All this should have a familiar sound to students of library management. There is little doubt that most library management and organization courses still depend heavily on these classical theories for the bases of formal organizations. The nature of such theories has caused students of library science to view library administration from a heavily discipline-oriented rather than problem-oriented viewpoint.

Among the familiar terms, principles, and ideas we have adopted from classical theory are "static," "prescriptive," "discipline," and "authority." Some definitions should be helpful in illustrating how classical theories have influenced library management. ${ }^{2}$

"Static" describes something which is fixed and unchanging during a long span of time. Filley and House explain that "Static theories usually suggest that $A$ causes $B$. That is, factor $A$ is both necessary and sufficient for result $B$." For example, the statement that a good salary scale attracts competent librarians means that a good salary scale is both necessary and sufficient to attract competent librarians.

"Prescriptive" describes a statement concerning what should be done or what should take place. A characteristically prescriptive statement in library management might be that library staff members work more efficiently with two fifteen-minute coffee breaks per day than with no coffee breaks at all.

${ }^{2}$ See forthcoming article in Management International by Robert J. House and Alan C. Filley: "Science, Theory, Philosophy and the Practice of Management." 
"Discipline-oriented" management theory results in the division of management principles among various fields of operation. One group of experts knows the principles of library management, another group knows the principles of hospital management, and so on.

"Authority" refers to the right to give commands from the top down. Such a system of authority is usually defined by an organizational position chart, in which, for example, the chief executive of a library commands a director of technical services, who commands the head of a cataloging department, who commands the head of a subject cataloging division, who commands individual catalogers, who command typists.

Weaknesses of the classical theories. The organization of libraries in this complex modern society owes much to the theoretical framework which the early classical theorists have provided. But it is important for librarians to be aware of the weaknesses in these theories on which they rely so heavily.

The influence of Classical theories in library management has resulted in a "principles" approach to organization. Some modern theorists question the validity of principles if they are defined as permanent universal laws. Strother goes so far as to say that "there is very little solid evidence for the universality of principles of organization. As a matter of fact, there is very little evidence as yet that there are any principles of organization, universal or otherwise." ${ }^{3}$

Another important defect of Classical theory is its undue emphasis on the formal aspects of organization. Based on the assumption that the worker's human nature leads him to seek the utmost material gain, it neglects entirely the effects of individual personality, informal groups, intra-organizational conflict, and

\footnotetext{
"George B. Strother, "Problems in the Development of a Social Science of Organization," in Harold J. Leavitt, ed. The Social Science of Organization (Englewood Cliffs, N. J.: Prentice-Hall, 1963), p. 21.
}

the decision-making process on the formal structure.

It is well for librarians to be aware that the principles of Classical organizational theories were formulated by successful managers by generalizing from their own experiences, and that they have not yet been subjected to rigorous empirical testing. March and Simon point out that "perhaps the most critical failure of classical administrative science is that it does not confront theory with evidence. ... The theories tend to dissolve when put into testable form."4

Human Relations school. The Human Relations school developed in the 1930's, compensating for some of the deficiencies in the Classical theories. The $\mathrm{Hu}$ man Relations school has its origins in the Classical school, but its main emphasis is on the individual and the informal group in the formal organization. The importance of this school is that it is mainly oriented towards and based on empirical research. The theories, however, are still static, discipline-oriented and prescriptive. The source of authority is still the formal organizational structure.

These shifts in focus from the formal to the informal aspects of organization reflect shifts in organizational characteristics and in management philosophy. In the early days of small-scale industrial activity, the idea that hard work and superior ability promised success in industry was widely accepted. The industrious worker could expect someday to establish his own factory and acquire the right to exercise authority over his employees. But when industry grew and the modern world became more complex, the early concepts of organization no longer gave a true picture. Probably hard work and superior skills are still important ingredients of success in complex modern organizations, but today one of the most important qualities of

4 James G. March and Herbert A. Simon, Organizations (New York: Wiley, 1958), p. 32. 
all seems to be skill in human relations. A pioneer study was done at the Western Electric Company's Hawthorne works in Chicago between 1927 and 1932. From it, came some results that generally disagree with many of the Classical organizational "principles." It showed that the quota of production is set by social norms, not by economic desires. It demonstrated that workers are more motivated by social rewards and sanctions than by economic incentives; that workers in their acts are influenced by the group; and finally, that wherever formal organization exists, both formal and informal norms exist and the informal norms are established by informal leaders. ${ }^{5}$

As a result of this study, much further research has been done in the field of human relations. After World War II, such research became quite commonplace. From these studies a large body of theory has developed relating to motivation, coordination, leadership, informal status, communication, and so on.

In general, human relations theory relates organizational structure and work to the social needs of the employees. If the organization makes employees happy, the argument goes, it will gain their full cooperation and effort, thus reaching optimum efficiency.

Library management and organization have not yet taken full advantage of the theories of the Human Relations school, although such phrases as "staff participation in library management," "communication techniques," "decentralization," and so on are frequently used.

Criticism of the Human Relations school. The Human Relations school assumes, like the Classical theories, that worker satisfaction and productivity do not have to conflict. Modern theorists generally disagree with the view that the workers' needs and organizational

\footnotetext{
${ }^{5}$ F. J. Roethlisberger and William J. Dickson, Management and the Worker (Cambridge, Mass.: Harvard University Press, 1939).
}

needs can be perfectly harmonized. The conflict between the worker and the organization, they hold, is inevitable, like autonomy $v s$. discipline, superior $v s$. subordinate, and formal vs. informal relations.

The Human Relations school does not regard the worker as an economic man who will increase his productivity for material rewards. It does not emphasize the formal aspects of organization. Rather, it encourages management to let employees develop social groups on the job, develop employee participation in management, democracy in the organization, communication with informal leaders and groups, and the like. Modern theorists, however, have criticized the "unrealistic happy dream" of being able to manipulate the work group by such inexpensive gifts as affection, esteem, prestige in work, and so on.

Research in the field of human relations suffers from incompleteness. There is a lack of integration of the many facets of human behavior that have been studied. ${ }^{6}$ Modern theorists charge that too much of the empirical research done by the Human Relations theorists has been confined to business and industry. They also claim that it is biased in favor of management in many instances.

Modern organizational theory. While Classical and Human Relations theories still prevail throughout most of the management and organization discipline, there has been a growing dissatisfaction with the deductive, prescriptive, and "principles" approach to management and organization. While the major emphasis on modern organizational theory and research dates from the 1950 's, it originated in 1938, when Chester Barnard, the father of behavioralism, published a book called The Functions of an Executive. The behavioralists, including M. Haire, C. Argyris, R. Stogdill, and

William G. Scott, "Organization Theory: an Overview and an Appraisal," in Joseph A. Litterer, ed. Organizations: Structure and Behavior (New York: Wiley, 1964), p. 19. 
others, are primarily interested in research and theory in regard to individual and group behavior. They operate in various fields, or disciplines, such as business, psychology, political science, and sociology.

A second group of researchers including A. Gouldner, A. Etzioni, P. Selznick and others, is primarily composed of sociologists who are interested in subjecting classical organization theory to empirical testing. Unlike the behavioralists, these scientists usually investigate the total organization rather than small groups.

A third category, led by H. A. Simon, R. Cyert, J. G. March and others, is the management science group. These scholars base their research primarily on actual observation of the phenomena in question followed by abstract analysis of the results. They "build models"systems of ideas which are supposed to represent and approximate real life situations, and from which they attempt to prescribe and predict. $^{7}$

These modern organization theorists, unlike the theorists of the Classical schools, tend to emphasize 'empirical research and description and generalization from large bodies of concrete data. They do not present absolute statements but confine themselves to general statements of probability. Their empirical theories depend heavily on statistical formulations and tests.

The source of authority, according to modern theorists, is political rather than economic. That is to say, authority does not come from an employee's defined position alone, but from many other sources as well, such as competence, personality, loyalty of subordinates, and the like. The modern approach does not, like the Classical and Human Relations schools, limit its research to business and

\footnotetext{
These classifications of modern organization theory are drawn from A. C. Filley's unpublished ms., chapter four, "The Evolution of Management Theory," p. 18-19.
}

industry, but rather it studies every kind of organization, from social clubs and prisons to military organizations and churches.

'The modern organizational school is problem-oriented rather than disciplineoriented. In other words, for any particular problem it chooses to study, it takes advantage of the findings of anthropology, sociology, economics, political science, mathematics, and so on. It does not try to be rigidly prescriptive, to advise what must be done if certain goals are to be achieved. It limits itself largely to descriptions of the phenomena it studies.

To borrow a summary of modern organizational analysis from Etzioni, modern theorists are concerned with:

1. Both formal and informal elements of the organization and their articulation.

2. The scope of informal groups and the relations between such groups inside and outside the organization.

3. Both lower and higher ranks.

4. Both social and material rewards and their effects on each other.

5 . The interaction between the organization and its environment.

6 . Both work and nonwork organization. ${ }^{8}$

- Stogdills Theory an example of modern contributions. Ralph Stogdill's theory of individual behavior and group achievement ${ }^{9}$ is a good example of a modern theory which can contribute valuable new insights to library management. Unfortunately, it is not possible to describe the entire theory and all its ramifications in this brief article, but

${ }^{8}$ Amitai Etzioni, Modern Organization (Englewood Cliffs, N. J.: Prentice-Hall, 1964), p. 49.

R. M. Stogdill, Individual Behavior and Group Achievement (New York: Oxford University Press, 1959). For an excellent summary and analysis, see Alan C. Filley and Robert J. House," "A Note on Current Organization Theory: a Summary and Analysis of Stogdill's Theory of Individual Behavior and Group Achievement," Wisconsin Project Reports, v. 2, No. 4. Bureau of Business Research and Service, School of Commerce, University of Wisconsin, 1965. 
perhaps the following examples will illustrate the kinds of new ideas that could be gained by further study of modern management literature.

Stogdill's theory synthesizes and explains the results of more than eight hundred research studies. One of the most revolutionary new ideas he proposes is that managers should never measure the output of their organization in terms of productivity alone. The output of a catalog department, he would say, should not be measured solely in terms of the number of books cataloged or cards typed and filed. The manager should be equally concerned with developing an eager and responsive staff which can be depended on under diffcult as well as favorable conditions. Only in achieving a balance between these different kinds of output can a manager really attain optimum efficiency. He should never sacrifice the intangible output of his organization for the sake of impressive statistics, or vice versa.

Stogdill's theory is particularly successful in resolving the conflicts between Classical theorists and behaviorālists. The behavioralists have minimized the importance of formal organizational structure. The Classical theorists, in contrast, have always tended to feel that the more completely defined an organization's structure is, the more efficiently that organization will function. Stogdill, however, has shown convincingly that an intermediate amount of structure leads to optimum efficiency and the greatest satisfaction and freedom among employees. If the employees of a library are not clear about what rules they are expected to follow, what hours to keep, to whom they are responsible, what and how much they are expected to do, and so on, they will waste a great deal of time just checking, confirming, seeking approval to do one thing or another, and generally trying to find out what is expected of them. A struc- tural vacuum such as this may well be filled by informal group norms which do not contribute very much to organizational efficiency.

On the other hand, if the routines of library work are very rigidly prescribed and supervised, the employees will become bored and frustrated. While they may be pressured into higher productivity over the short run, the resulting dissatisfaction will cause a net reduction in productivity in the long run.

With an intermediate degree of formal structure, the employees will know exactly what is expected of them but will also be left some choice as to how they use their time and carry out their tasks. This will contribute to optimum total output. This new approach should be seriously considered both by library managers who seek to avoid making rules at all costs, and those who would like to reduce every activity to a written routine.

Some managers of the old school feel that informal group relations have no place on the job. While they find such activities hard to control, their ideal is to eliminate them entirely. An economically motivated worker, they argue, should not want to waste valuable time in, and is not being paid for, such activities. The behavioralists feel, however, that a staff member who is not so restricted will be happier and therefore more efficient.

None of the research done on this subject has fully supported either side. Employees do not give their best efforts to organizations which try to extinguish all social contact on the job. And yet, if they are left almost completely alone, they may be perfectly happy and very unproductive. The Classical and Human Relations schools had assumed that workers' needs and organizational goals did not conflict, and they could not explain these discrepancies.

Stogdill draws an important connection between structure and output. Un- 
der intermediate degrees of formal struc- $L$ ture, when the needs of the employees and of the organization are harmonized, the existence of informal groups actually contributes to efficiency.

For firm believers in extensive division of labor, Stogdill's theory offers a warning. Classical theorists assumed that because the assembly line method of working increases productivity it should be accepted wholeheartedly by employees. This has not proved to be the case. Studies show that the boredom and frustration of employees who must do the same tiny, undignified, and automatic motions day after day tends to cause an over-all drop in long-run efficiency. Experiments in job enlargement have had very promising results. While extreme division of labor may give short-run benefits, people tend to do better work when their jobs have enough challenge in them that they can take some pride in doing them well. This pride and the satisfaction the employees can take in their work must also be considered part of the output of the organization.

Conclusions and some suggestions. It should be emphasized that the Classical and Human Relations theories must not be undervalued. These remain the basic framework of our management discipline. H. Koontz wrote that:

Every thoughtful business executive who wants to make his practice of management more effective should be concerned with the development of an accurate and useful theory of management. Any art-and managing is surely one of the most important arts-is improved by the discovery, understanding, and proper application of theory by those who know how to use it. ${ }^{10}$

Library managements and students of library management could benefit also by taking advantage of the latest developments in management and organization theories. We have already drawn heavily on classical and human rela-

\footnotetext{
${ }^{10}$ Harold Koontz, ed., Toward a Unified Theory of Management (New York: McGraw-Hill, 1964), p. 1-2.
}

tions theories for our management of libraries and training of librarians. These dynamic new developments will no doubt be absorbed into library management as well.

Many libraries, unfortunately, have been criticized for ineffectiveness, bad service, and other defects. Some librarians have come to feel that libraries will always receive criticism from patrons who do not understand their problems. Criticism seems to have become an accepted part of library life. One scholar has suggested that libraries can survive in spite of criticism only because they are social institutions occupying a monopolistic position. Could they survive, however, if libraries became commercialized and began to compete as business organizations? Libraries, like any other public service institution, have an obligation to manage themselves as efficiently and effectively as possible.

Organizations differ in their characteristics and goals but some of their essential qualities, such as efficiency, effectiveness, and survival and growth are similar. A broadening of scope and study of the problems librarianship has in common with many other kinds of organizations would prove fruitful. Many academic disciplines have now become problem-oriented in their management and organization courses. For example, at the University of Wisconsin, courses in organization and administration in the school of commerce, the sociology department, the engineering department, and the policial science department draw material from the same bodies of theory and research. Library schools could perhaps improve their practices in the matter as well.

In 1933, Pierce Butler warned that:

Unlike his colleagues in other fields of social activity, the librarian is strangely uninterested in the theoretical aspects of his profession. He seems to possess a unique immunity to that curiosity which elsewhere drives modern man to attempt, somehow, 
an orientation of his particular labors with the main stream of human life. ${ }^{11}$

Onemight ask if this statement still applies to the library profession.

The importance of research in library management cannot be denied. Empirical research could give new dimensions and insights into the ways libraries should operate. It can give choices of action, suggest desirable action, and give predictions of possible outcomes. If librarianship is to advance as an academic discipline as well as a profession, it must put more emphasis on its research obligations in the field of management. E. J. Reece has observed that:

It must have meaning, for example, to find even a few leaders recognizing that the attitudes of librarians to administration has been hamperingly empirical; that their professional literature on the subject has been scant and immature; that research so far has imparted little to its history and rationale; that the administration of libraries does not differ materially from that of other organizations; and that librarians could profit from the knowledge and experience gained and the practice tested in other fields where administration is requisite. ${ }^{12}$

${ }^{11}$ Pierce Butler, An Introduction to Library Science (Chicago: University of Chicago Press, 1961), p. xixii.

${ }_{12}$ Ernest J. Reece, "Introduction," Library Trends, VII (January 1959), 335.
BIBLIOGRAPHY

Argyris, C. Personality and Organization. New York: Harper, 1957.

Barnard, C. I. The Functions of the Executive. Cambridge: Harvard University Press, 1938.

Cyert, R. M., and J. G. March. A Behavioral Theory of the Firm. Englewood Cliffs, N. J.: Prentice-Hall, 1963.

Davis, R. C. The Fundamentals of Top Management. New York: Harper, 1951.

Etzioni, Amitai. Complex Organizations. New York: Holt, Rinehart \& Winston, 1961.

Fayol, Henri. General and Industrial Management. New York: Pitman, 1949.

Gouldner, A. W. Patterns of Industrial Bureaucracy. Glencoe, Ill.: Free Press, 1954.

Gulick, L. and L. Urwick, eds. Papers on the Science of Administration. New York: Columbia University Press, 1937.

Haire, Mason, ed. Modern Organization Theory. New York: Wiley, 1959.

Mooney, J. D. and A. C. Reiley. Onward Industry. New York: Harper, 1931.

Selznick, P. Leadership in Administration. Evanston: Row, Peterson, 1957.

Simon, H. A. Administrative Behavior. 2d ed. New York: Free Press, 1965.

-Taylor, Frederick W. The Principles of Scientific Management. New York: Harper, 1911.

Weber, Max. Theory of Social and Economic Organization. New York: Oxford University Press, 1947.

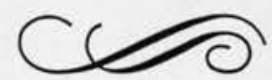

